\title{
Improving the Performance Management of Public Institutions: Is it Difficult to Measure Performance in Public Institutions?
}

\author{
Andreea TUDOR ${ }^{1}$
}

DOI: $10.24818 / \mathrm{mer} / 2021.12-01$

\begin{abstract}
In recent years, measuring the performance of public institutions has become a topic much studied by researchers, as questions arise about its structure and role in the economy and society, whether it is effectively put in the public service and whether it is effective or not.

To improve the management system, there is a need to introduce a performance management whose main goal is the evaluation of performance at individual and organizational level along with the improvement of the efficiency of public expenditures and the orientation towards achieving the results.

This paper aims to highlight the importance of performance measurement and explain the role of it in the development of the public institutions. The results were obtained after analyzing numerous qualitative and quantitative data and an extensive research was conducted to filter the information found in various research platforms, official electronic resources and numerous books related to performance management, performance evaluation system, characteristics and possible barriers that may occur while trying to measure the performance in the public sector.

Moreover, since public sector performance is closely linked to the overall economic performance of different countries this research paper comes to complete the existing literature, leaving room for further research on the topic discussed.
\end{abstract}

KEYWORDS: public sector, performance, management, public institution

JEL CLASSIFICATION : $D 7, D 73, H 83$

\section{INTRODUCTION}

The public sector consists of a system of institutions that influences the lives of all people who are part of a community. This sector is responsible for a very large part of economic activity. In most developed countries, the public services sector accounts for about $20 \%$ of employment and 15\% of GDP (Gross domestic product). Given the importance of this sector, innovation is one of the key factors in social welfare, productivity growth, and long-term employment (Windrum \& Koch, 2008).

Public institutions must be able to meet the challenges of the contexts that are taking place both economically and socially in order to take advantage of the opportunities offered by new technologies. Such opportunities are represented by the development of new services that are oriented towards openness, transparency and include the participation of citizens (OCDE, 2011).

\footnotetext{
${ }^{1} \mathrm{PhD}$ Student, Bucharest University of Economic Studies, email: tudorandreead@yahoo.com
} 
Although the perception of performance management seems to be a recent discovery, records show that this is something that began in the early 1900s at the New York Council, where it was customary to set targets and analyze data (Williams, 2003). However, the term „performance management” was not used until 1970s (Armstrong \& Baron, 2004). In the early 2000s, it was already an established aspect when it comes to public sector management with many journals writing about the subject (Ferlie \& Steane, 2002). Of course, since it was a relatively new thing, there were different levels of confusion around this subject (Brown, 2005). Concerns began to appear whether the main focus should be on the results and if it's appropriate for the public sector or not.

Looking at a study that covers numerous international experiences, it seems that managers are agreeing: performance measurement is needed with focus on efficiency within the public sector (Behn, 2002) because it allows institutions to plan and implement strategies to influence the organizational behavior, compel, focus, monitor and reward employees.

Buschor (2013) presents the Performance Management evolution in the four phases as follows:

1. Traditional phase (before 1978) - characterized by control over inputs and cash accounting;

2. Managerial phase (between 1978 and 1995) - characterized by attempts to introduce managerial methods and techniques as well as accrual accounting in public sector institutions;

3. Marketisation phase (between 1986 and 1992) - characterized by a combination of managerial ideas and economic theories with an emphasis on competitive markets, selfinterest and contracts. In this phase, financial management reforms have become an integral part of the extensive changes in public institutions;

4. Strategic phase (starting from 1992 to the present) - characterized by a focus on the strategy and on the long-term point of view in order to overcome the fragmentation that was created during the previous phase.

The modernization of the methods, techniques and practices exercised by the organizations that carry out their activity within the public sector has become an extremely important subject that has registered a substantial increase in the conditions of the changes in the society to which are added the new tendencies of the management (Popovici \& Popovici, 2019).

Performance evaluation is useful for designing the strategy of public institutions (Choong, 2013). Before starting, public managers need to ask one simple question "why do we measure performance?". Mainly performance is measured to see how much progress has been done and whether intervention is needed or not. (Osborne \& Gaebler, 1992) encourage public institutions to measure performance in the book "Reinventing government: how the entrepreneurial spirit is transforming the public sector". The main argument of the book is summarized below with bullet points:

- If you don't measure the results, you cannot distinguish success from failure;

- Without seeing success, you cannot reward it;

- If you cannot reward progress or success, you will most likely reward failure;

- If you can't see progress or success, you can't learn from them;

- Without acknowledging the failure, you cannot correct it;

- If you can demonstrate and be transparent about the results, you have the chance to gain public support. 
(Yake, 2005) claims that it is very important to know who your customers are and to have a clear picture, know their standards and characteristics such as accuracy, timeliness, easy access, long term benefit and so on. Once those are established it's important to take in consideration how and if performance can be measured. Moreover, if the measurement is done right it can be done at a high cost and it's important to review if the benefits outweigh the costs.

By conducting this study, I want to emphasize the importance of measuring performance, explain its role in the development of public institutions and inform about possible barriers that may hinder the measurement of performance in the public sector. To evaluate the previously mentioned facts extensive research was needed. As a research method, I found appropriate to use a descriptive one, mainly because the topic is widely discussed in the literature. However, to complement the existing literature a comprehensive analysis was needed to see if there are any gaps and how the results of this paper can help alleviate them. To accomplish this objective, data was collected from PROQUEST Central, ProQuest ebooks, Elsevier Ebooks, Emerald Management EJournals, Web of Science, official electronic resources and many books related to the subject discussed, which fueled the research.

This study is structured as follows. Firstly, targeting to analyze the role of performance measurement in the development of public institutions and secondly having as focal point the barriers that can appear when institutions are measuring performance. It is also imperative to see if it's important to measure performance and clarify why it's benefic for public institution. As soon as these aspects are discussed this study continues with the research methodology. Finally, this paper addresses future research opportunities and provides recommendations for making performance measurement more practical and efficient.

\section{LITERATURE REVIEW}

\subsection{The role of performance measurement and the development of public institutions}

In recent years, measuring the performance of public institutions has become a topic long studied by researchers. They study the design, implementation, application and content of measurement systems. Many of these studies show that balanced performance measurement is also applicable in public organizations, so there is a common view, namely, that performance management is viewed differently in public companies than in private ones (Rantanen et al., 2007).

Taxes fund public services and most people prefer exquisite public services. This reluctance was partly based on a general dislike of paying more taxes, but it was also a realization that running more money does not automatically lead to better services. Additional taxes may, for example, go towards paying higher salaries for the staff providing those services, but there may not be any improvements to the actual service. There must be a way to know whether public services are worth the money and whether they are appropriate. It may also be necessary to ensure that the process by which the services are provided meets appropriate standards. There is no doubt that performance measurement may not be an easy and straightforward process and that political debates about priorities may be involved (Pidd, 2012).

Performance measurement can be done by virtuously following the three Es (Stefanescu et al., 2010): 
Economy is a cost-based approach and it's easy to be measured, but costs are inputs rather than outputs, and therefore doesn't tell nothing about how well a public program achieves its goals;

$>$ Efficiency it's represented by the ratio between the results obtained in the economic activity and the efforts made; (Marcu, 2000)

Effectiveness it's achieved by comparing the results with the predictions or objectives previously proposed.

In addition, there is one more $\mathrm{E}$ which stands for Equity and it's also included by many public programs. Equity answers to the following question: Is there evidence that the program treats people fairly or that its advantages are dispersed unequally among the citizens it is supposed to serve? It's important to distinguish between horizontal and vertical equity. Horizontal equality is accomplished when all people are treated equally, whereas vertical equity is obtained when people with varied needs are individually, not collectively (Pidd, 2012).

To evaluate employee performance, every company should have a performance appraisal system. Organizations must realize that performance appraisal systems with a wide range of features and large price tags are not necessarily helpful. A performance appraisal system will be effective if certain qualities are combined and that's mainly because measurement attributes possess measurement characteristics and each performs a different measurement role (Choong, 2013).

Table 1. Characteristics of an efficient performance measurement system

Key factors
-Involvement of all company
members in the process
- Creating a solid culture of
learning and assessment
- Managerial willingness to
invest resources to achieve
results

Efficient performance measurement system

- Understanding performance indicators

- Greater motivation to achieve results

- Greater use of performance information for both learning and feedback
The resulting performances

-More honesty and transparency in reporting results

-Improved performance and efficiency

-Innovation and new strategies to improve performance

Source: Adapted from Goh (2012)

Performance measures are systematic qualitative or quantitative evaluations throughout time of what an organisation is, how well it functions, and the effects of its activity. Below are some of the most common reasons to measure performance:

1. To find what works: people wish to receive high-quality services, and governments want them to be provided efficiently. Therefore, it makes sense to measure performance, to see which measures are the most effective and efficient. This can be done by public service managers who want to promote learning and improvement or could be imposed by a central group.

2. To determine functional competence: most of the public services are provided by local branches in locations across a country or region. Some are provided by local contractors that are operating under service level agreements. Another reason for measuring performance is to identify people with high performance and to understand why they are doing so well and to encourage best practices.

3. To encourage public accountability: public services are financed mainly by taxation, and in democracies it seems reasonable for the public to know how well the services are provided. 


\subsection{Barriers in measuring public service performance}

The performance appraisal system is extremely demanding for civil servants in management positions because it requires time, training, legitimacy, transparency, and trust within the team, especially when it comes to promotions (Ministère de la Fonction Publique, 2005).

Public organizations are under the constant pressure to provide more and better services. This can be done by increasing the transparency of public management and by monitoring the results of the public sector. In this sense, performance evaluation is presented as a tool that can contribute to the prioritization of projects and a better allocation of public resources (Ensslin et al., 2015).

This focus on results has not been very successful in the public domain. At the generic level, this focus on results has raised concerns about the weakening link between managers/employees and the organization. More specifically, qualitative and empirical research has shown that the use of these assessment tools has changed human resource management and decision-making styles within organizations (Modell, 2004)

Public sector organizations have recently received increasing criticism for placing too much emphasis on financial control, as well as for the excessive proliferation of performance indicators. A solution to those two problems was presented in the form of various multidimensional and goal-oriented strategic models for measuring performance, such as Balanced Scorecard and Performance Prism which will be discussed below (Modell, 2004).

Balanced Scorecard is a management performance tool that helps to include the financial aspects of an institution and the non-financial key measures linked to clients or customers, organizational learning, internal processes and growth needs. Therefore, using a specific scorecard is helpful when it comes to measuring and monitoring performance (CGMA, 2013).

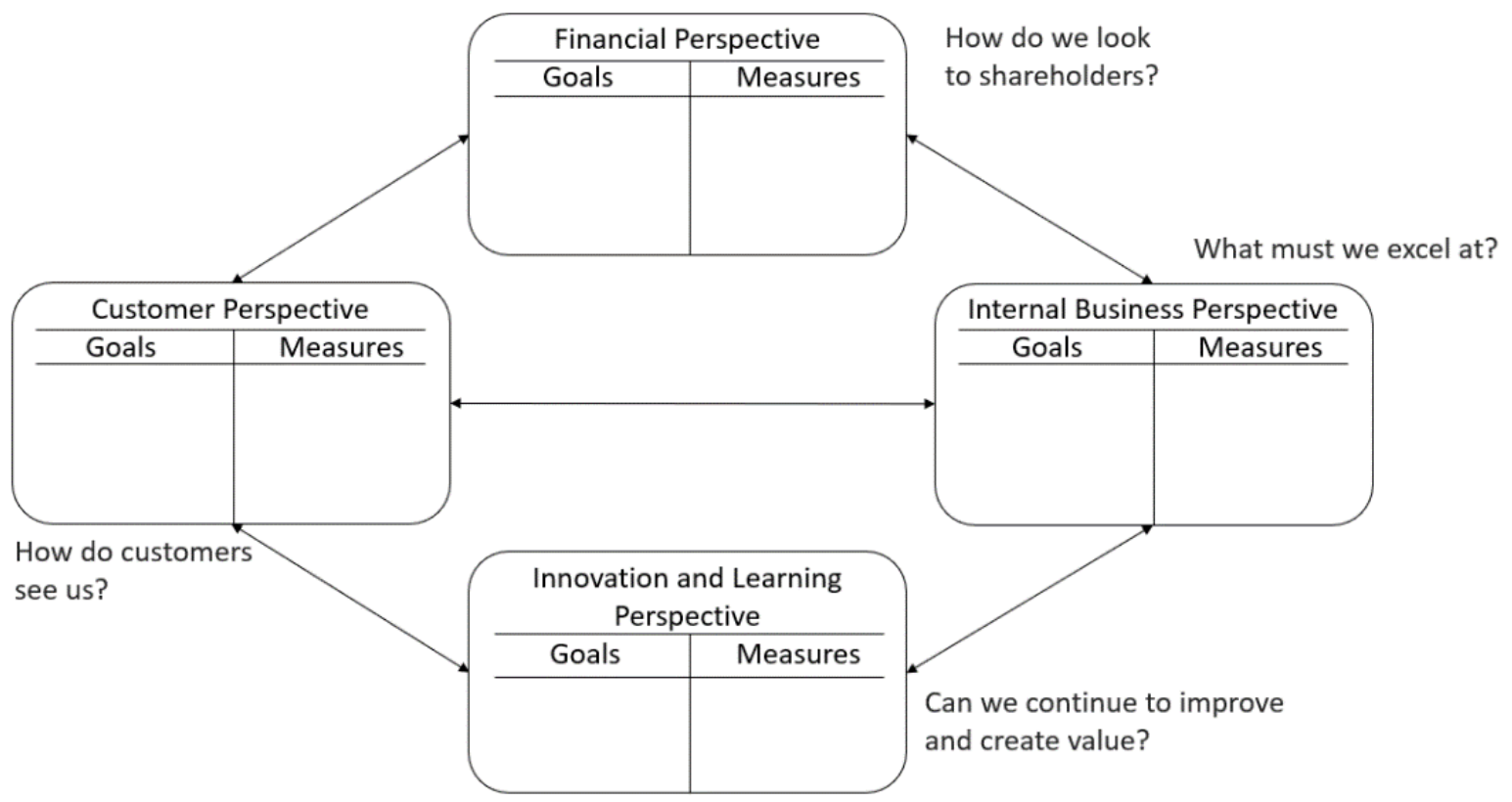

Figure 1. Representation of Balanced Scorecard

Source: adapted from (Kaplan \& Norton, 1996) 
The Balanced Scorecard concept provides means to clarify, express and communicate strategy. It represents a short way to put all the key measures in a "dashboard" that can be successfully used to monitor and evaluate the results. By adding non-financial measures, institutions can assess how non-financial aspects of performance, such as customer satisfaction, translate into financial performance. Balanced Scorecard proves to be a useful tool when it comes to employee motivation, while focusing on the factors that are considered essential for long-term performance, rather than short-term financial results (Rafiq et al., 2020).

Worldwide, the Balanced Scorecard has an adoption rate of approximately $66 \%$ having as sample managers of large companies (Rigby \& Bilodeau, 2007). For example, in the United States of America, the Balanced Scorecard has 35\% adoption rate having as sample fortune 5000 companies (Marr, 2005), United Kingdom with 57\% adoption rate in large companies (Anonymous, 2001) and other countries like India with $45 \%$ in large companies (Anand et al., 2005), Sweden with 38\% in Technical and industrial companies (Olve \& Petri, 2004) and Norway with $30 \%$ in manufacturing companies (Olsen, 1999).

The Performance Prism is considered a 'second generation' balanced scorecard and management structure by the Cranfield University developers because it has as starting point the institution stakeholders (customers, intermediaries, investors, suppliers, employees, communities, regulators) rather than strategy (CGMA, 2013).

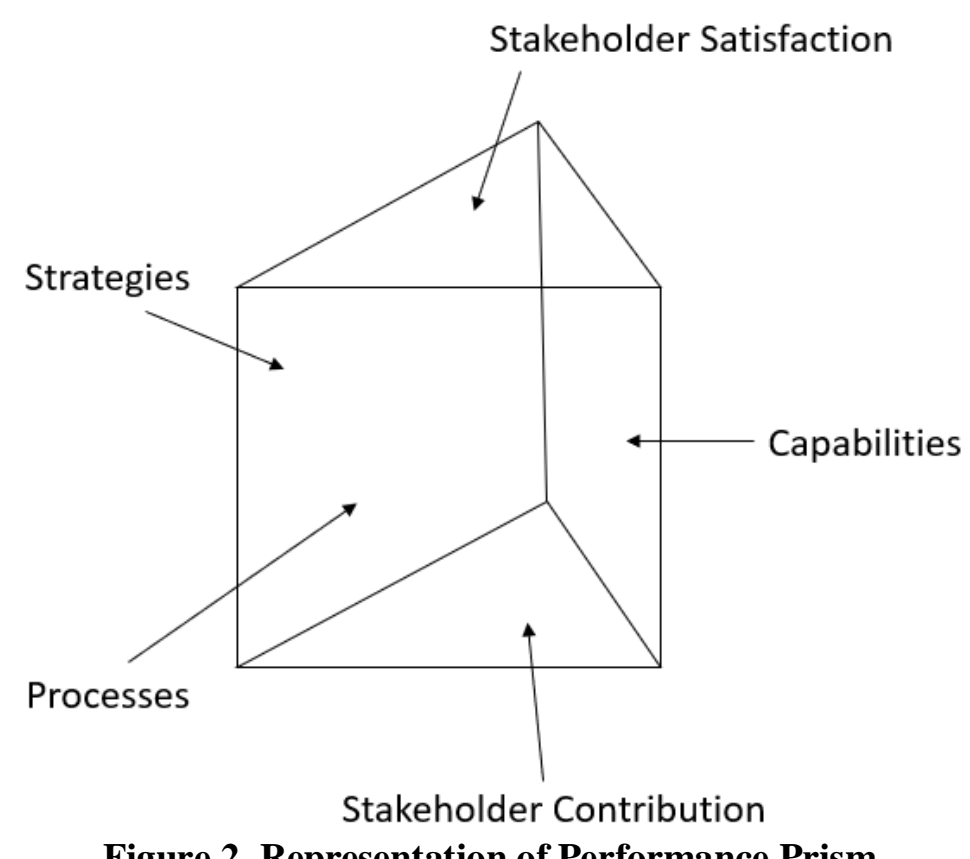

Figure 2. Representation of Performance Prism

Source: adapted from (Neely, Adams, \& Kennerley, 2002)

The five pylons of the Performance Prism come along with key questions for strategy conception and performance measurement design (Neely et al., 2002):

$>$ Stakeholder Satisfaction: Who are the stakeholders and what do they need or want?

$>$ Strategies: What are the strategies that we need towards satisfying the needs?

$>$ Processes: What are the processes that we need in order to execute the strategies?

$>$ Capabilities: What are the capabilities that we need to perform our processes more efficiently and effectively? 
Stakeholder Contribution: What do we need and want from our stakeholders if we desire to maintain and develop these capabilities?

One of the main benefits of the Performance Prism is that has as center of attention the stakeholders that can be customers, the owners as well as employees, suppliers, regulators or society in general (Severgnini et al., 2018).

Focusing on the public sector, most of the institutions have a small and restricted budget, the financial insufficiency being a real obstacle. The shortcomings of such a system do not allow for stability and, as a result, unfair payments are often made, as well as performance-based payment which has proven to be demoralizing and inefficient.

This focus on results has not been very successful in the public domain. At the generic level, the focus on results has raised concerns about the weakening link between managers/employees and the organization.

\section{RESEARCH METHODOLOGY}

The purpose of this chapter is to provide a theoretical context and a rationale plan for collecting and analyzing primary and secondary data to achieve the objectives of this study. This study begins with an introduction that provides a brief context on performance management and also a summary of the paper. The literature review has two parts. The first one explains how performance measurement can have an impact on the development of public institutions and the second one presents the barriers that may arise while measuring the performance in public institutions.

The research continues with the methodology, which is this chapter. To accomplish the goal of the research paper, I used numerous qualitative and quantitative data. The method I used is descriptive, mainly because the topic is very widely discussed in the literature and because it comes with several benefits:

$>$ Various data collection: Data used was found in PROQUEST Central, ProQuest ebooks, Elsevier Ebooks, Emerald Management EJournals, Web of Science and other official electronic resources. Since I used the main research platforms, I believe the data found is high quality. Those platforms are providing quick and easy access to the main research engines that can be accessed through (Enformation) which powers research in corporate, public, academic, government, school libraries worldwide. Access to these resources is offered to me by the Bucharest University of Economic Studies.

$>$ Provides detailed information: The data use is qualitative and quantitative, which gives a holistic approach to public sector performance management and offers extensive information about the area of interest.

$>$ Provides the basis for decision making: The data collected in this descriptive research is rich and various, which makes it a lot easier when I analyze it and formulate the recommendations and the conclusions.

Once these aspects are clarified, it is appropriate to formulate the results and the recommendations based on the information that was previously gathered. Therefore, the next chapter is dedicated to the results of the research and the last chapter presents the conclusions of this study and premises towards future research. 


\section{RESEARCH RESULTS AND DISCUSSIONS}

The performance approach is transposed through a management system whose main objective is to improve the efficiency of public spending and the orientation towards obtaining results. An efficient and effective measurement of performance can be done by following the $3 \mathrm{E}$ concept: Economy, Efficiency and Effectiveness. Moreover, it is good to consider that another $\mathrm{E}$ is present in most programs, which stands for Equity.

Excellence is more than a mixture of economy, efficiency and effectiveness. Even if managers choose to follow the 3Es concept or include the Equity to the concept it will result an excellent strategy of offering to the customer a proper services delivery of what they need and want at a cost that seems fair for the value that they receive. Basically, doing the right things at a fair price.

Public institutions are known for their financial control and this is mainly due to the inflexible budget and from the extensive proliferation of their performance indicators. A solution to overcome those two obstacles was presented in the form of various multidimensional and goal-oriented strategic models for measuring performance, such as Balanced Scorecard and Performance Prism. Both models promote evaluation from various perspective that are related to processes, learning, capabilities, innovation, stakeholders and customers.

Summarizing, performance measurement is a management tool based on taking decisions focused on output and outcome not primarily on the financial input. Looking at the figure below, it is logical to say that performance management is based on both the strategy and the mission of a public organization (Buschor, 2013).

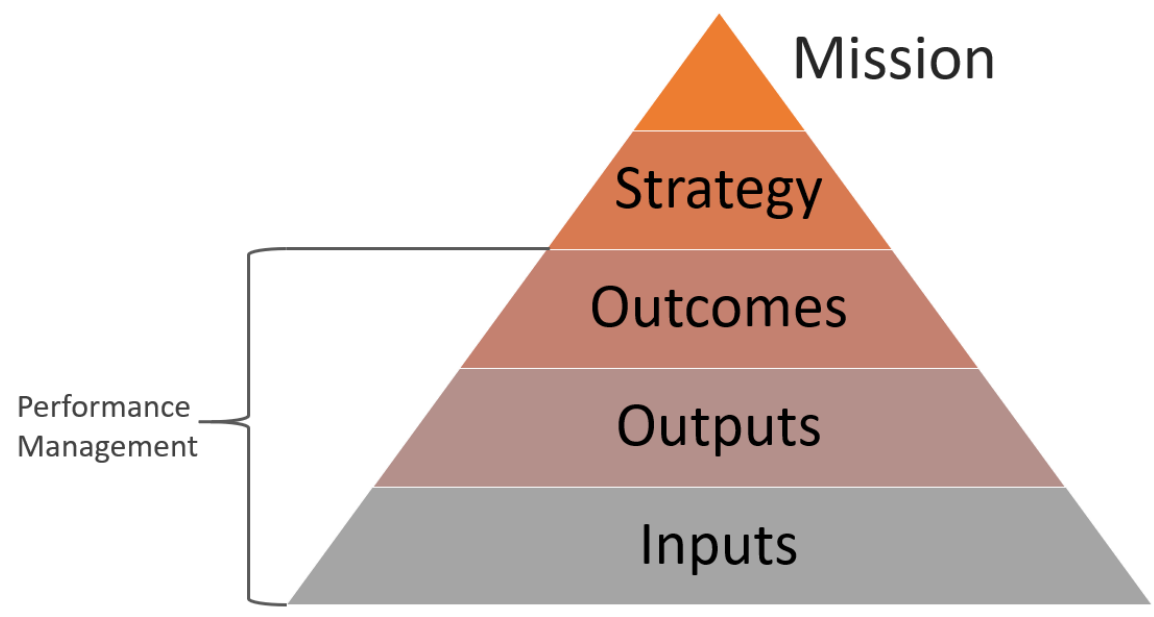

Figure 3. Representation of performance management tool

Source: adapted from (Buschor, 2013)

Measuring performance in the public sector has also some limitations. The results of this study suggest that public sector organizations need a trade-off between quantitative goals that are short-term performance goals (efficiency and quantity produced) and quality goals that are long-term strategic performance goals (quality / accuracy, employee morale).

Not being driven by the right motivation to measure performance can be the main barrier in the development of performance, in general, within the organization. Also, implementing a 
performance management system could be an expensive project, so organizations need to balance the benefits and disadvantages. Of course, all barriers can be overcome if the necessary effort is made. Many experts recommend making these efforts because the benefits can be many times greater.

To sum up, in this study I analyzed whether performance measurement is necessary for the public sector, whether it is necessary and whether it is difficult to implement. The results indicate that measuring public sector performance is necessary and usually, when it's done properly, comes with extraordinary benefits.

A recommendation of an effective performance measurement cycle may be as follows:

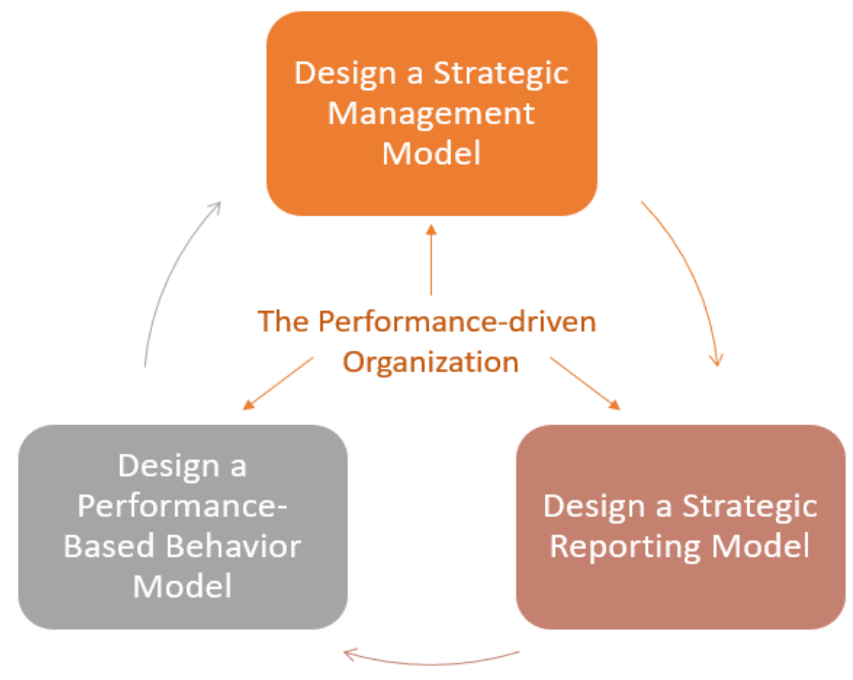

Figure 4. Strategic Performance Management Cycle

Source: adapted from (de Waal, 2007)

Based on the above model, an explicit version is presented below:

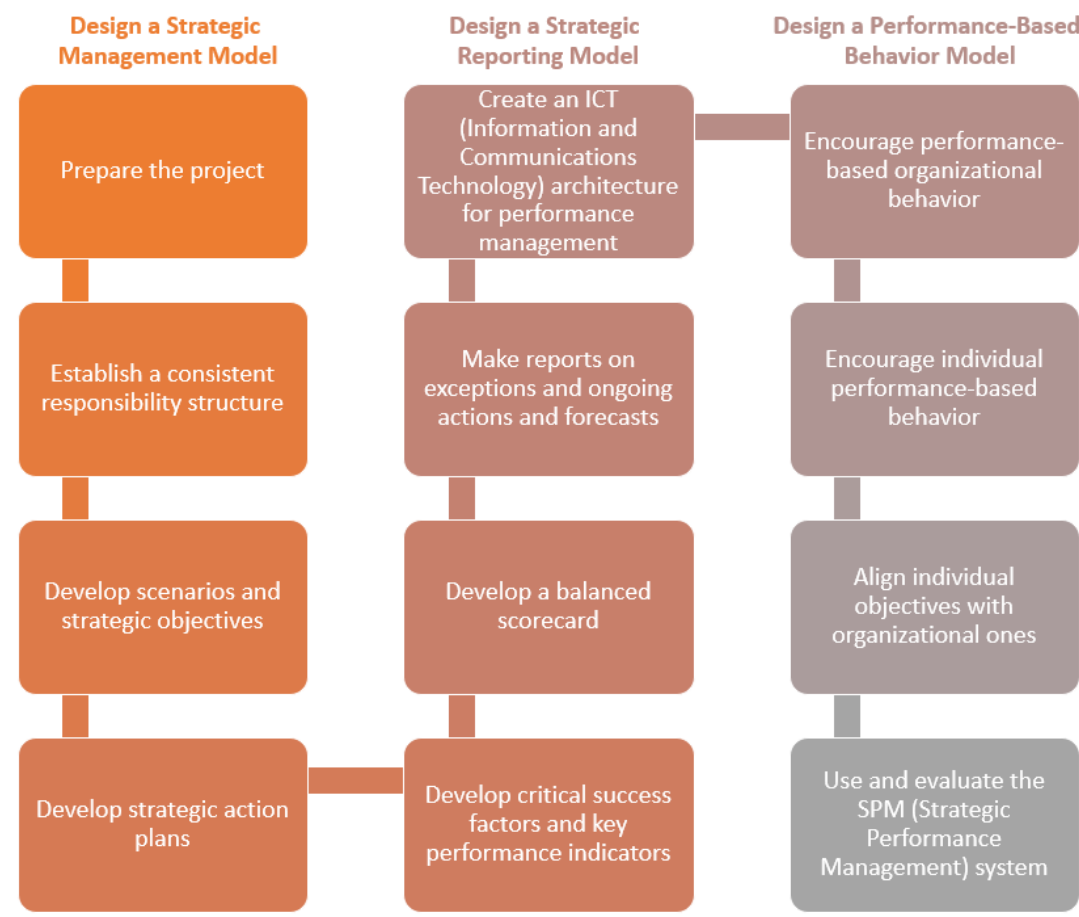

Figure 5. Representation of applying the Strategic Performance Management cycle Source: adapted from (de Waal, 2007) 
I want to mention that this is just one of the models for implementing a Strategic Performance Management cycle that can be found in the current literature.

\section{CONCLUSIONS}

It is very important for all organizations to clarify their goals and to choose the strategy that suits them best. The measurement of performance has traditionally been equated with the analysis of financial statements, which provides an understanding of the operations found in the financial statements or the reading of financial statements. The main shortcoming is the neglect of those hard-to-measure non-financial indicators and the orientation towards the past. By combining financial indicators with non-financial information, the institutions can have a complete picture of entity's operations.

No matter what methods or indicators are used for evaluating performance, a special emphasis should be placed on communicating them to the entire company, regardless of the hierarchical level, as well as sharing with the citizens. For example, if citizens have access to the process and results of public sector organizations, their confidence in the government could increase. Without doubt, performance measurement helps public institutions to plan better services, provide those services to users and increase public support. This increases the responsibility, allows regulatory requirements to be met in terms of the quality and cost of the services provided. In view of all the above reasons and facts, it is necessary to establish an effective system for measuring performance.

Given the context, there is a clear need to implement performance measurement systems in public institutions. Even If the institution is successful, the measurement of the performance is needed because it can be seen who deserves to be rewarded. On the other hand, if the company is underperforming it can be seen what needs to be improved.

Future research can be done following, for example, some of the routes presented below:

$>$ What is the employees' perception on the aspects related to performance management?

$>$ How well do lower-level managers (team leaders) and employees know their role in designing the performance management system?

$>$ Does the participation of lower-level managers (team leaders) and employees give them a sense of "ownership"?

$>$ How often do managers and employees have conversations about performance? Are the conversations formal or informal? Are those discussions valuable? If not, what is in the way? What are the other priorities?

\section{REFERENCES}

(n.d.). Retrieved from Enformation: https://www.e-nformation.ro/

Anand, M., Sahay, B., \& Saha, S. (2005). Balanced scorecard in Indian companies. Vikalpa, 30(2), 1125. Retrieved from http://nts2.ximb.ac.in/users/fac/Amar/AmarNayak.nsf/dd5cab6801f 1723585256474005327c8/456e5a8383adcf07652576a0004d9ba5/\$FILE/BSC-India.pdf

Anonymous. (2001). Balanced scorecard is fast becoming a must have process for corporate change. Management Services, 45(8), 5-6.

Armstrong, M., \& Baron, A. (2004). Managing Performance: Performance Management in Action. London: CIPD - Kogan Page. 
Behn, R. D. (2002, September). The Psychological Barriers to Performance Management: Or Why Isn't Everyone Jumping on the Performance-Management Bandwagon? Public Performance Management Review, 26(1), 5-25.

Brown, A. (2005). Implementing performance management in England's primary schools. International Journal of Productivity and Performance Management, 54(5/6), 468-481. doi:10.1108/17410400510604593

Buschor, E. (2013, July). Performance Management in the public sector: Past, current and future trends. Review of Applied Management Studies, 11(1), 4-9. doi:10.1016/j.tekhne.2013.05.005

CGMA. (2013, June 11). Balanced Scorecard Case Study. Retrieved from https://www.cgma.org/resources/tools/essential-tools/balanced-scorecard.html

CGMA. (2013, June 11). The Performance Prism. Retrieved from https://www.cgma.org/resources/ tools/essential-tools/performance-prism.html

Choong, K. K. (2013). Understanding the features of performance measurement system: a literature review. Measuring Business Excellence, 17(4), 102-121.

Choong, K. K. (2013, November ). Understanding the features of performance measurement system: A literature review. Measuring Business Excellence, 17(4). doi:10.1108/MBE-05-2012-0031

de Waal, A. d. (2007). Successful performance management? Apply the strategic performance management development cycle! Measuring Business Excellence, 11(2), 4-11. doi:10.1108/13683040710752698

Ensslin, L., Lacerda, R., Krüger, A. C., \& Chaves, L. C. (2015). DISCLOSURE OF THE FIELD PERFORMANCE EVALUATION IN THE PUBLIC SECTOR IN INTERNATIONAL JOURNALS. Revista de Gestão, Finanças e Contabilidade, 5(3), 75-99. doi:10.18028/22385320

Ferlie, E., \& Steane, P. (2002). Changing development in NPM. International Journal of Public Administration, 25(12), 1459-1469. doi:10.1081/PAD-120014256

Goh, S. C. (2012). Making performance measurement systems more effective in public sector organizations. MEASURING BUSINESS EXCELLENCE, 16, 31-40. Retrieved from https://www-emerald-com.am.enformation.ro/insight/content/doi/10.1108/13683041211204653/full/pdf?title=makingperformance-measurement-systems-more-effective-in-public-sector-organizations

Kaplan, R. S., \& Norton, D. P. (1996). The Balanced Scorecard : Translating Strategy into Action. Boston, MA, United States of America: Harvard Business Review Press.

Marcu, F. (2000). Marele dicționar de neologisme. Saeculum. Retrieved from DEX Online: https://dexonline.ro/definitie/\%20optimizare

Marr, B. (2005). Performance measurement: an overview of the current state of use in the USA. Measuring Business Excellence, 9(3), 56-62. Retrieved from https://www.emerald.com/insight/ content/doi/10.1108/mbe.2005.26709caf.006/full/html

Ministère de la Fonction Publique. (2005, Iulie). Enquête sur les systèmes de management par objectifs et de reconnaissance de la performance. Direction générale de l'administration et de la fonction publique - GRH et LOLF: Gestion et reconnaissance de la performance. Retrieved from Le portail de la Fonction publique: https://www.fonction-publique.gouv.fr/files/files/ publications/archives_ressources_humaines/grh_lolf_2005.pdf

Modell, S. (2004). Performance measurement myths in the public sector: a research note. Financial Accountability and Management, 20(1), 39-55. doi:10.1111/j.1468-0408.2004.00185.x

Neely, A., Adams, C., \& Kennerley, M. (2002). The Performance Prism: The Scorecard for Measuring and Managing Business Success. London: Financial Times/ Prentice Hall.

OCDE. (2011). Making the Most of Public Investment in a Tight Fiscal Environment: Multilevel Governance Lessons from the Crisis, Paris. . Paris: Organizatia pentru Cooperare si Dezvoltare Economică.

Olsen, L. E. (1999). The Balanced Scorecard: styringsdimensjoner $i$ norsk industri - en empirisk unders $\phi k e l s e$. Bergen: Norwegian School of Economics and Business Administration.

Olve, N. G., \& Petri, C. J. (2004). Balanced scorecard i svenska teknikföretag. Hösten, Stockholm, Sweden: Rapport til Teknikföretagen.

Osborne, D., \& Gaebler, T. (1992). Reinventing government : how the entrepreneurial spirit is transforming the public sector. New York: Reading, Mass. : Addison-Wesley Pub. Co. 
Pidd, M. (2012). Measuring the Performance of Public Services: Principles and Practice. New York, United States of America: Cambridge University Press. Retrieved from https://www.cambridge.org/gb/academic/subjects/management/organisation-studies/measuringperformance-public-services-principles-and-practice?format=HB\&isbn=9781107004658

Popovici, A., \& Popovici, C. (2019). PROBLEME ALE GESTIUNII PERFORMANȚEI FUNCT⿱IONARILOR PUBLICI. Administrarea Publică, 2, 27-33.

Rafiq, M., Zhang, X., Yuan, J., Naz, S., \& Maqbool, S. (2020, February 13). Impact of a Balanced Scorecard as a Strategic Management System Tool to Improve Sustainable Development: Measuring the Mediation of Organizational Performance through PLS-Smart. Sustainability, 12, 1-19. Retrieved from 10.3390/su12041365

Rantanen, H., Kulmala, H. I., Lonnqvist, A., \& Kujansivu, P. (2007, July 17). Performance measurement systems in the Finnish public sector. International Journal of Public Sector Management, 20(5), 415-430.

Rigby, D., \& Bilodeau, B. (2007). Bain's global 2007 management tools and trends survey. Strategy \& Leadership, 35(5), 9-16. Retrieved from http://www.management.free.fr/sauv/general/ Bain's_global.pdf

Severgnini, E., Galdaméz, E., \& Moraes, R. d. (2018, Mar/Apr). Satisfaction And Contribution Of Stakeholders From The Performance Prism Model. Brazilian Business Review, 15(2), 120-134. doi:10.15728/bbr.2018.15.2.2

Smith , P. C., \& Street, A. (2005). Measuring the Efficiency of Public Services: The Limits of Analysis. Journal of the Royal Statistical Society. Series A (Statistics in Society), 168(2), 401417.

Stefanescu, A., Dobrin, C., Calu, D. A., \& Turlea, E. (2010). Controverse privind masurarea performantei entitatilor administratiei publice din Romania. Revista Transilvană de Ştiinţe Administrative, 25(1), 225-242.

Williams, D. W. (2003). Measuring Government in the Early Twentieth Century. Public Administration Review, 63(6), 643-659. doi:10.1111/1540-6210.00329

Windrum, P., \& Koch, P. (2008). Innovation in Public Sector Services: Entrepreneurship, Creativity and Management. Cornwall, United Kingdom: MPG Books Ltd, Bodmin, Cornwall. Retrieved from https://books.google.co.uk/books?hl=en\&lr=\&id=LhpHU90oztcC\&oi=fnd\&pg=PR1\&dq= Windrum, + P., + Koch,+ P.+(2008), + Innovation+\%C3\%AEn+Public+Services:\&ots=_25GCuXTj Y\&sig=w62hqm9XLQgCY3-9zVzbSNiuGwc\&redir_esc=y\#v=onepage\&q\&f=true

Yake, W. (2005). Performance measurement in Fairfax County, Virginia. Virginia, United States. Retrieved from blogs.nasa.gov/cm/wiki/FederalKnowledgeManagementWorkingGroup (KMWG) 